\title{
Drivers of Entrepreneurial Intentions in the Context of the Covid-19 Pandemic
}

\author{
John James Cater, III \\ The University of Texas at Tyler \\ Marilyn Young \\ The University of Texas at Tyler \\ Marwan Al-Shammari \\ The University of Texas at Tyler \\ Kevin James \\ The University of Texas at Tyler
}

\begin{abstract}
This study investigated the effect of the personality factors, creativity, risk-taking, and locus of control, on the entrepreneurial intentions of U.S. business college students, employing the theoretical lens of the theory of planned behavior. We surveyed 353 student respondents, comparing those with self-reported entrepreneurial intentions ( $n=213)$ versus those without entrepreneurial intentions $(n=140)$. Our results indicated that the personality characteristics of risk-taking and creativity both significantly and positively predicted entrepreneurial intentions, but locus of control did not have a significant impact. Contextually, this study was undertaken during the extensive difficulties of the Covid-19 pandemic. One positive consequence of the pandemic has been a heightened interest in entrepreneurship. We advise business school educators to pursue activities that encourage nascent entrepreneurship by fostering creativity and providing educational initiatives that help students reduce the perceived risk of starting their own businesses.
\end{abstract}

Keywords: entrepreneurial intentions, personality factors, pandemic, theory of planned behavior, survey method

\section{INTRODUCTION}

The role of the manager is changing in part due to the Covid-19 pandemic. We perceive a movement toward self-employment as the pandemic shakes the corporate structure. Individuals have been encouraged to work at home rather than commute to the office. The pandemic may loosen the corporate bonds of allegiance to the employer and stimulate a movement toward starting one's own business. In this article, we seek to encourage nascent entrepreneurs and support start-up businesses. Although many start-up companies have failed, there has been a surge in creativity and an increase in entrepreneurial activity in 
response to the Covid-19 crisis (World Economic Forum, 2020). The onset of the pandemic in March 2020 in the U.S occasioned a dramatic decline in new business start-ups. The U.S. Census Bureau tracks "highpropensity" business applications, a subset of applications for new Employer Identification Numbers (EINs). Such applicants have a high probability of becoming new businesses and hiring employees within a few months. Although employer applications fell off by 50,000 in March and April of 2020, the trend reversed in the remainder of the year. Through December 10, 2020, there have been almost 189,000 more applications filed than through the same time point in 2019, an increase of 15\% (O'Donnell, 2020).

Even in difficult times, entrepreneurship improves productivity, spurs innovation, and creates new jobs, according to the Center for American Entrepreneurship (2020). Significantly, seeking an understanding of why individuals desire to start their own businesses is a beginning to comprehend entrepreneurship. Recognizing start-up desires or entrepreneurial intentions and examining the factors that lead to selfemployment aspirations are critical issues (do Paco, Ferreira, Raposo, Rodrigues, \& Dinis (2011). The focus of this study is on the intentions stage of the entrepreneurial process.

Entrepreneurial intentions may predict future entrepreneurial behavior (Krueger, Reilly, \& Carsrud, 2000). The theoretical base for entrepreneurial intentions is the theory of planned behavior (Ajzen, 1988; 1991), which proposes that an individual's performance of a specific behavior is a function of the intention to perform that behavior, assuming the individual behaves reasonably. Therefore, an individual will perform a behavior given the extent that they possess the required opportunities and resources and the intention to perform the behavior (Nishimura \& Tristan, 2011).

Entrepreneurial intentions are built upon both personal and contextual factors. For many years, psychologists have studied personal factors, while management scholars have more recently joined (Caliendo, Fossen, \& Kritikos, 2010). Personal factors include entrepreneurial experience, personality characteristics, abilities, education, family background, cultural background, and gender (Boyd \& Vozikis, 1994; Linan \& Fayolle 2015). Contextual factors include economic variables, such as corporate downsizing, market shifts, and governmental regulatory changes (Bird, 1988) and social phenomena, including the Covid-19 pandemic. While the pandemic has heightened the interest of both business school educators and students in entrepreneurship (World Economic Forum, 2020), we propose that personality factors are still integral to entrepreneurial intentions. Moreover, personality characteristics play a significant role and add important information to the development of entrepreneurial intentions (Caliendo et al., 2010).

Scholars have examined a wide variety of personality factors that may affect entrepreneurial intentions. Among the factors were self-confidence and leadership capacity (Hopp \& Sonderegger, 2015), attitudes towards entrepreneurship (do Paco et al., 2011), alertness to opportunities (Arenius \& Minniti, 2005), the Big Five personality characteristics (Caliendo et al., 2010), self-efficacy (Brachert, Hyll, \& Sadrieh, 2019), and tolerance of ambiguity (Altinay, Madanoglu, Daniele, \& Lashley, 2011).

We chose to study three of the most reputable predictors of entrepreneurial intentions -risk-taking propensity (Caliendo et al., 2010), creativity (Schmidt, Soper \& Facca, 2012), and locus of control (Rotter, 1966). We selected these three variables because entrepreneurship scholars have regularly employed them in entrepreneurial intention studies worldwide and found significant results (Linan \& Fayolle, 2015). We applied a survey approach to test hypotheses that compared the personality factors of risk-taking propensity, creativity, and locus of control of students with entrepreneurial intentions against those who did not have entrepreneurial intentions. Therefore, the research question was, do risk-taking propensity, creativity, and internal locus of control drive entrepreneurial intentions?

This study makes several critical contributions regarding personality factors, entrepreneurial intentions, and the theory of planned behavior. First, we seek to increase awareness among business school educators that entrepreneurship is a feasible and desirable career choice. Second, we provide further evidence that personality factors influence entrepreneurial intentions beyond contextual factors, even the Covid-19 pandemic. Third, we confirm studies worldwide supporting the effect of personality factors on entrepreneurial intentions and the theory of planned behavior. Fourth, although studies have examined each of the three variables, we have not found them together. Fifth, we have not found the three variables in one U.S.-based study. Finally, we encourage business school educators to provide counsel for nascent 
entrepreneurs to grow in their risk-taking propensity, expand on their creativity, and understand that many entrepreneurship elements lie within their control.

In the remainder of this paper, we will review the theoretical background of entrepreneurial intentions, postulate hypotheses, describe the method used, explain the results, provide a discussion of the results, propose implications for business school educators, and convey study limitations and possibilities for future research.

\section{THEORETICAL BACKGROUND AND HYPOTHESIS DEVELOPMENT}

The next section of the paper examines current theory in the following areas: the theory of planned behavior, entrepreneurial intentions, risk-taking propensity, creativity, and locus of control and the development of hypotheses to investigate the interaction of these variables.

\section{The Theory of Planned Behavior and Entrepreneurial Intentions}

There are three assumptions in the theory of planned behavior; (1) that individuals normally behave reasonably, (2) that they contemplate available information, and (3) that they evaluate the consequences of their actions (Nishimura \& Tristan, 2011). Beginning with the works of Shapiro (Shapero, 1984; Shapero \& Sokol, 1982), studies of entrepreneurial intentions have increased. An intention is a state of mind that focuses an individual's attention on a specific form or object of behavior (Bird, 1992). In this study, we use the following definition of entrepreneurial intention: an individual's judgments and attitude toward the likelihood of developing one's own business (Grant, 1996; Sun, Ne, Teh, \& Lo, 2020). According to entrepreneurial intention studies, the most obvious way to predict behavior is to understand current intentions. An underlying assumption is that individuals can plan the behavior and that an individual has a choice in the process (Sun et al., 2020). According to the theory of planned behavior, intentions indicate the effort individuals are willing to give to perform a behavior. Generally, the stronger the intention to engage in a behavior, the more likely it will be undertaken (Nishimura \& Tristan, 2011).

The most common reasons given by entrepreneurs to start their own business include autonomy (being their own boss), financial gain, and intrinsic benefits, such as pride of achievement, possession of discretionary power, and recognition from others as a business owner (Douglas \& Fitzsimmons, 2013). Before starting their own business, many entrepreneurs gain work experience in a specific industry or work in small firms, requiring them to learn multiple tasks and skills (Sorgner \& Fritsch, 2017).

\section{Risk-Taking Propensity}

Risk-taking may be defined as the willingness to act based on the perception of possible future gains or losses (Jackson 1994). Entrepreneurs who accept high levels of risk are willing to sustain high levels of variability in the gains or losses of future choices. Conversely, a low risk-taking propensity would indicate a willingness to accept only low levels of variability in the gains or losses of future choices (Gartner \& Lioa, 2011). Scholars have considered risk-taking propensity to be one of the most significant entrepreneurial characteristics (Altinay et al., 2011) and the most widely studied variable relating to entrepreneurial intentions (Caliendo et al., 2010). Entrepreneurship scholars have researched risk propensity more than any other personality characteristic because business ownership is, by nature, risky. Therefore, it is reasonable to infer that more risk-tolerant individuals are more likely to become entrepreneurs (Fairlie \& Holleran, 2012).

Individuals with higher reported risk-taking propensities are more likely to start their own businesses (Brachert et al., 2019). Studies have shown that entrepreneurs are moderate risk-takers, not gamblers (Koh, 1996). Entrepreneurs seek to reduce the risk in new ventures with feasibility analyses, business model development, and business plans that seek well-calculated risk (Caliendo et al., 2010). Alternatively, entrepreneurs may perceive risk differently so that what may appear to be a risky situation to others may seem less difficult to entrepreneurs (Janney \& Dess, 2006). According to Hisrich, Peters, \& Shepherd (2002), entrepreneurship activities are full of risks, and the ability to take calculated risks with confidence leads to achieving entrepreneurial objectives. Self-employed individuals tend to be less risk-averse than 
those in corporate employment (Caliendo et al., 2010). Additionally, in a study of Spanish immigrant entrepreneurs, Hormiga \& Bolívar-Cruz (2014) suggested that people who are more inclined to take risks are more likely to become entrepreneurs. Thus, the ability to tolerate higher levels of risk should assist nascent entrepreneurs in starting a new business. Therefore, we hypothesize the following.

\section{Hypothesis 1: There is a positive relationship between propensity to take risks and entrepreneurial intentions.}

\section{Creativity}

Creativity is the ability to produce original ideas and new products or services (Melati, Areif, \& Baswara, 2018) and thought processes to generate a competitive advantage in the global marketplace (Shrader \& Finkle, 2015). Therefore, creativity consists of producing both novel and practical works (Sternberg \& Lubart, 1999). According to researchers, creativity is essential to entrepreneurship (Schmidt et al., 2012).

In a 2010 study, the American Management Association found that creativity and innovation were two of the four skills needed for business success (Schmidt et al., 2012). With the rapid technological advances occurring within the worldwide economy, creativity is a critical skill required to identify opportunities and satisfy customer needs (Shrader \& Finkle, 2015). Creativity consists of four components, known as the four Ps: person, product, process, and press (Davis, 2004). Self-report measures of individual characteristics usually assess the person dimension. The product component refers to creative output or products made in the past. The process component is evaluated by using measures of divergent thinking. The press dimension often gauges the encouragement of creative activities by an organization (Schlee \& Harich, 2014). The value of personal creativity and product creativity may be easily discerned, but process creativity, employing divergent thinking, may also be of growing importance. In the global economy, individuals in varied cultures with distinct values will need to think creatively to solve problems (Schmdt et al., 2012).

Business school educators should be encouraged to note that an individual's creativity may be augmented through training. Researchers have found that training has enhanced the creative process and has improved subjects' creativity (Schlee \&Harich, 2014). Therefore, business school educators should incorporate creativity training. For many years, scholars have called for the inclusion of creative exercises within entrepreneurship education (Timmons, 1994). Morrison and Johnston (2003) asserted that creativity should be instilled in every course throughout the entrepreneurship curriculum.

Although there have only been a few empirical studies, the relationship between creativity and entrepreneurial intentions has been supported (Laguia, Moriano, \& Gorgievski, 2019). In a survey of Greek engineering university students, those with higher self-perceived creativity reported higher entrepreneurial intentions (Zampetakis \& Moustakis, 2006). Managerial creativity also includes a strong focus on identifying opportunities. Researchers view creativity as critical to entrepreneurial intent or behavior because it is linked with identifying opportunities that lead to the development of new businesses (Ko \& Butler, 2007). Zampetakis et al. (2011) examined the effect of creativity on entrepreneurial intentions of people who are not yet entrepreneurs and found that individuals' perceived creativity is likely to lead them to start their own business. In a U.S. study, Schmidt et al. (2012) reported that entrepreneurship students performed better than non-entrepreneurship students in the creative exercises of divergent thinking and flexibility. Therefore, we hypothesize the following.

\section{Hypothesis 2: There is a positive relationship between creativity and entrepreneurial intentions.}

\section{Locus of Control}

Locus of control, initiated by Rotter (1966), refers to an individual's perception of events contingent on one's characteristics or actions or beyond their control. An individual possesses internal locus of control if he/she believes that the sources of events are linked to their behavior or characteristics. In contrast, people with an external locus of control think that what happens to them depends on external causes, such as destiny, chance, or fate (Brunel, Laviolette, \& Radu-Lefebvre, 2017). Rotter's (1966) work focused on the 
conception that individuals were more likely to change their behavior when they believed in internal control following a negative or positive reinforcement than people with an external locus of control. In the U.S., society has placed a high value on independence and autonomy. Although Rotter (1975) cautioned against labeling all characteristics of individuals with internal control as positive and all qualities of people with external control as unfavorable, researchers and practitioners have assumed that internal locus of control is preferable (Marks, 1998).

Locus of control is a significant factor in the development of entrepreneurial intentions (Krueger, 2009). Mescon and Montanari (1982) compared independent entrepreneurs and franchisees on locus of control, using Rotter's (1966) scale. Both samples scored higher than the national average, but the independent entrepreneurs outperformed the franchise operators. In another study, Cromie (1987), using interview data, found that entrepreneurs scored significantly higher on internal locus of control than managers. Researchers have found advantages for individuals who possess an internal locus of control compared to those with an external locus of control. Internal locus of control allows individuals to reduce their stress and increase their motivation and performance in many situations (Judge et al., 2002). Individuals with internal locus of control face challenges positively and seek creative solutions to problems (Luthans et al., 2006). Those with internal locus of control display higher achievement motivation and are more willing to learn and develop their knowledge, skills, and abilities (Hsiao, Lee, \& Chen, 2016). Therefore, we hypothesize the following.

Hypothesis 3: There is a positive relationship between internal locus of control and entrepreneurial intentions.

\section{METHOD}

\section{Research Subjects}

For this study, we have chosen university business school students as the research subjects. Entrepreneurial intentions research based on established firms is prone to a "survival bias" because the qualities that lead to business survival are not necessarily the same as those leading to starting a business, and studying existing firms leaves out many cases of start-ups that failed (Johnson, Parker, \& Wijbenga, 2006). Therefore, scholars have turned to the use of university students as research respondents in entrepreneurial intentions studies around the world, including Austria (Schwarz, Wdowiak, Almer-Jarz, \& Breitenecker, 2009), China (Sun et al., 2020), France (Brunel et al., 2017), Hong Kong (Koh, 1996), Portugal (do Paco et al., 2011), and Romania (Luca \& Cazan, 2011). Nevertheless, there have been a limited number of studies addressing the entrepreneurial intentions of business school students in the U.S. Of course; there have been many studies using U.S. business school students, such as Schlee and Harich's (2014) study on creativity. This study focused on business school undergraduate students at a central U.S. state regional university. We believe that this is a better representation of nascent entrepreneurs than existing businesspeople. Nascent entrepreneurs may be defined as individuals actively trying, either alone or with others, to start a new business (Carter \& Han, 2015).

\section{Sample and Data Collection}

We used a sample of 353 business school students from a southwest U.S. state regional university. The primary reason for using students as a sample was to study the entrepreneurial intention processes before starting a business. Therefore, we could include both respondents with entrepreneurial intentions and those without entrepreneurial intentions in one sample (Krueger, 2009). As others have done, we did not assume that attendance in an entrepreneurship class is evidence of entrepreneurial intentions (Schmidt et al., 2012). Students attend classes for other reasons, such as completing a required regimen of courses to reach graduation. Further, the self-reported survey focused on students who reported entrepreneurial intentions $(n=213)$ versus those without entrepreneurial intentions $(n=140)$. A secondary reason for surveying university students was to allow us to control for the level of education, which may influence entrepreneurial intentions (Altinay et al., 2012). 
Before beginning the study, we obtained permission to research human subjects from the university's institutional review board. We provided informed consent and anonymity to all respondents. We used the Qualtrics software system to gather the 353 survey responses online, and students received a dedicated link to complete the survey.

\section{Measurements}

We measured all variables with pre-existing scales and adapted survey items from previously established sources. We employed items from the Risk Propensity Scale 1 by Meertens and Lion (2008) to measure risk-taking. We used the Creativity Audit Questionnaire from the Creativity Development \& Innovation Training Package for Small and Medium-sized Enterprises (2013) to measure creativity. We utilized items from Locus of Control, based on J.B. Rotter (1966) Generalized expectancies for internal versus external control of reinforcement, Psychological Monographs, 80, (1, Whole No. 609). Finally, we used the Entrepreneurial Intention items from do Paco et al. (2011).

To increase the accuracy of the measurement, we ran a principal component analysis to ensure that the items loaded on one factor that corresponded to the latent variable being measured. For the variable risktaking, two items were reverse coded. The four items used to measure the variable loaded on one factor with an Eigenvalue of 1.99 and explaining 49.7 of the variance. Factor loadings ranged from 0.34 to 0.56 . Cronbach alpha was 0.64 with an average inter-item covariance of 0.34 . Creativity was measured using four items, and the PCA yielded one factor with an Eigenvalue of 2.29, explaining 57.2 percent of the variance. Factor loadings for the four items ranged from 0.46 to 0.54 . Cronbach alpha was 0.75 with an average inter-item covariance of 0.25 . lastly, locus of control was measured using five items, two of which were reverse coded. The items loaded on two factors with Eigenvalues of 1.7 and 1.09, respectively. Thus, we dropped one item from the first factor, which had a factor loading value of -0.09 . The loadings of the remaining items ranged from 0.27 to 0.62 . Cronbach alpha was 0.52 with an average inter-item covariance of 0.22 .

We addressed common method bias by using the Harmon Single Factor Test. Here, when all independent variables are force loaded into a single principal axes factor, we see that the single factor accounts for $20.4 \%$ of the variance. This amount is far less than the percentage of variance that would indicate that common method bias is a concern (Fuller, Simmering, Atinc, Atinc, \& Babin 2016). Students were not paid for participating in the survey. The participants completed a self-report questionnaire.

\section{Analysis and Model Estimation}

We used the Qualtrics program to gather the data and to determine frequencies for each survey question. Next, we transferred the data to SPSS and Excel for future statistical analysis. We used logistic regression to determine the relationship between students' intention to start a business and the personality variables of risk-taking, creativity, and locus of control. We employed a survey question stating: "Are you planning to start a business?" The dependent variable was defined as the intention to start a business, allowing the respondents to answer "yes" or "no." Therefore, using the logistic regression estimation method, we applied a robust standard errors technique to ensure that our results were unbiased.

Also, we further analyzed the variables using Chi-square $\left(\mathrm{X}^{2}\right)$ tests of independence to examine the relationship between the three personality variables (risk-taking, creativity, and locus of control) and respondent intentions to start a business. We also applied the test to age, gender, and ethnicity to determine if significant relationships existed.

\section{SURVEY RESULTS}

The results in this section show respondent demographics, business experience, overall work intentions, and entrepreneurial intentions concerning risk-taking, creativity, and locus of control. We seek to increase awareness among management consultants that entrepreneurship is a viable and desired career choice. Then, we report on our analysis of respondent personality traits and entrepreneurial intentions, which indicate significant characteristics of nascent entrepreneurs. 


\section{Demographic Characteristics of Respondents}

From a total of 454 students taking Entrepreneurship courses in the Spring, Summer, and Fall semesters of 2020, we obtained 353 usable surveys after removing duplicate responses for a response rate of $77.8 \%$. We provide descriptive characteristics of our respondents in the following areas: gender, ethnic background, age, education, and marital status. See Table 1. Of the 353 respondents, 188 (53\%) were male, and 165 $(47 \%)$ were female. The median age was 23 years old, with a range from 18 to 50 years. The reported ethnicity was $64 \%$ white, $13 \%$ African-American, and $17 \%$ Hispanic, which approximated the university's racial makeup. The most significant number of respondents was 21-23 (47\%), with an average age of 23 . A vast majority, $80 \%$, were under 30 with a small number, $20 \%$ over 30 . Most of the respondents $(70 \%)$ were single. Also, the sample consisted of $92 \%$ upperclassmen (seniors and juniors), $6 \%$ underclassmen (sophomores and freshmen), and 1\% graduate students. Many students were business majors (86\%), with the remainder minoring in business.

TABLE 1

DEMOGRAPHIC CHARACTERISTICS OF RESPONDENTS

\begin{tabular}{|l|l|l|l|}
\hline Gender & No. & $\begin{array}{l}\text { \% of Total } \\
(\mathbf{n = 3 5 3 )}\end{array}$ & $\begin{array}{l}\text { \%of those with } \\
\text { Entrepreneurial } \\
\text { Intentions }\end{array}$ \\
\hline Male & 188 & $53 \%$ & $60 \%$ \\
\hline Female & 165 & $47 \%$ & $63 \%$ \\
\hline Total & 353 & $100 \%$ & \\
\hline Ethnic/Race & & & $55 \%$ \\
\hline White & 227 & $64 \%$ & $81 \%$ \\
\hline Black & 44 & $13 \%$ & $64 \%$ \\
\hline Hispanic & 61 & $17 \%$ & $57 \%$ \\
\hline Other & 21 & $6 \%$ & \\
\hline Total & 353 & $100 \%$ & \\
\hline Age & & & \\
\hline $18-20$ & 30 & $9 \%$ & \\
\hline $21-23$ & 165 & $47 \%$ & \\
\hline $24-26$ & 59 & $16 \%$ & \\
\hline $27-29$ & 27 & $8 \%$ & \\
\hline 30 \& Over & 72 & $20 \%$ & \\
\hline Total & 353 & $100 \%$ & \\
\hline Classification & & & \\
\hline Freshman & 6 & $2 \%$ & \\
\hline Sophomore & 16 & $4 \%$ & \\
\hline Senior & 258 & $73 \%$ & \\
\hline Graduate & 5 & $1 \%$ & \\
\hline Total & 353 & $100 \%$ & \\
\hline Marital Status & 270 & $77 \%$ & \\
\hline Single & 83 & $23 \%$ & \\
\hline Married & 353 & $100 \%$ & \\
\hline Total & & & \\
\hline & & \\
\hline
\end{tabular}


We analyzed the demographics of age, gender, and ethnicity to determine if a relationship existed regarding the respondents' intention to start a business. Using the logistic regression model, we found that age and gender were not statistically significant predictors of the students' entrepreneurial intentions. However, African American ethnicity was statistically significant $(\mathrm{B}=1.22, \mathrm{P}<0.01)$. Of the African American students, $81 \%$ indicated they wanted to start their own business. Also, Pearson Chi-square was conducted and showed a significant difference among African American ethnicity and starting a business $(\mathrm{x} 2=11.5$ ( 3 d. f., $\mathrm{p}=.009)$.

\section{Overall Work Intentions}

A vast majority, $94 \%$, of the student respondents stated they planned to enter paid employment after graduation. However, $60 \%$ indicated they eventually planned to start a business. When asked, "How many years in the future do you plan to open your business," the range was from less than a year to over ten years. The average number of years students planned to start a business was within the one to five-year range (47\%). See Table 2.

TABLE 2

\section{OVERALL WORK INTENTIONS OF RESPONDENTS}

\begin{tabular}{|l|l|l|}
\hline Plans to Enter Paid Employment & & \\
\hline Yes & 332 & $94 \%$ \\
\hline No & 21 & $6 \%$ \\
\hline Total & $\mathbf{3 5 3}$ & $\mathbf{1 0 0} \%$ \\
\hline Plan to start a Business & & \\
\hline Yes & 213 & $60 \%$ \\
\hline No & 140 & $40 \%$ \\
\hline Total & $\mathbf{3 5 3}$ & $\mathbf{1 0 0 \%}$ \\
\hline & & \\
\hline How many years in the future do you plan to start your own business? & & \\
\hline Less than 1 year & 25 & $12 \%$ \\
\hline 1 to 5 & 98 & $46 \%$ \\
\hline 6 to 10 & 74 & $35 \%$ \\
\hline Over 10 & 16 & $\mathbf{7 \%}$ \\
\hline Total & $\mathbf{2 1 3}$ & $\mathbf{1 0 0} \%$ \\
\hline
\end{tabular}

\section{Entrepreneurial Intentions}

Next, we report the relationships between the personality variables - risk-taking, creativity, and locus of control - with entrepreneurial intentions. See complete results in Table 3, and the Correlation Matrix for all constructs, including control variables, is available in Table 4.

Referring to Table 3, we entered only the control variables in the base model (Model 1). In Model 2, we added our first independent variable, risk-taking. As shown in model 1, the coefficient of the variable risk-taking is positive and statistically significant $(\mathrm{B}=0.98, P<0.01)$, lending support to Hypothesis 1 , which proposed a positive relationship between risk-taking propensity and entrepreneurial intentions. Compared to Model 1, the Pseudo R2 significantly increased from 0.03 to 0.1 , which confirms the significance of the added variable (risk-taking).

To test Hypothesis 2, we entered our second independent variable in Model 3. Here, creativity was highly significant, and the coefficient was positive $(\mathrm{B}=0.56, P<0.05)$, providing support to our second hypothesis. Additionally, the Pseudo R2 significantly increased from 0.10 to 0.11 , which shows that 
variable creativity increased the model prediction power. Lastly, we added the locus of control variable in Model 4, and it was not a significant predictor statistically of entrepreneurial intentions in our sample. Age and gender were not statistically significant predictors of the students' entrepreneurial intentions, whereas African American ethnicity was statistically significant $(\mathrm{B}=1.22, P<0.01)$. See Table 3.

In addition, Chi-square $\left(\mathrm{X}^{2}\right)$ analysis shows a positive relationship between both risk-taking and creativity and student intentions to start a business. The Chi-square $\left(\mathrm{x}^{2}\right)$ value of 28.0 regarding risk-taking and student intentions was significant $(\mathrm{p}<.01)$. Creativity and student intentions had a Chi-square $\left(\mathrm{x}^{2}\right)$ of 6.05 and, therefore, was also statistically significant $(\mathrm{p}<.05)$. Again, this additional analysis matched the logistic regression estimation and showed that the locus of control variable and student intentions were not statistically significant.

TABLE 3

LOGISTIC REGRESSION RESULTS

\begin{tabular}{|c|c|c|c|c|}
\hline VARIABLES & $\begin{array}{l}\text { (Model 1) } \\
\text { Entrepreneurial } \\
\text { Intentions }\end{array}$ & $\begin{array}{l}\text { (Model 2) } \\
\text { Entrepreneurial } \\
\text { Intentions }\end{array}$ & $\begin{array}{l}\text { (Model 3) } \\
\text { Entrepreneurial } \\
\text { Intentions }\end{array}$ & $\begin{array}{l}\text { (Model 4) } \\
\text { Entrepreneurial } \\
\text { Intentions } \\
\end{array}$ \\
\hline \multirow{3}{*}{ Risk-taking } & & Risk-taking & Creativity & Locus of Control \\
\hline & & $0.977 * * *$ & $0.884 * * *$ & $0.882 * * *$ \\
\hline & & $(0.185)$ & $(0.185)$ & $(0.185)$ \\
\hline \multirow[t]{2}{*}{ Creativity } & & & $0.556 * *$ & $0.551 * *$ \\
\hline & & & $(0.226)$ & $(0.225)$ \\
\hline \multirow[t]{2}{*}{ Locus of control } & & & & 0.218 \\
\hline & & & & $(0.204)$ \\
\hline \multirow[t]{2}{*}{ Gender } & -0.060 & 0.116 & 0.069 & 0.065 \\
\hline & $(0.222)$ & $(0.239)$ & $(0.242)$ & $(0.243)$ \\
\hline \multirow[t]{2}{*}{ Age } & 0.001 & 0.012 & 0.007 & 0.004 \\
\hline & $(0.016)$ & $(0.017)$ & $(0.017)$ & $(0.017)$ \\
\hline \multirow[t]{2}{*}{ Ethnicity1_1 } & -0.081 & -0.143 & -0.347 & -0.418 \\
\hline & $(0.463)$ & $(0.492)$ & $(0.526)$ & $(0.532)$ \\
\hline \multirow[t]{2}{*}{ Ethnicity1_2 } & $1.223^{* *}$ & $1.039^{*}$ & 0.830 & 0.772 \\
\hline & $(0.591)$ & $(0.618)$ & $(0.641)$ & $(0.647)$ \\
\hline \multirow[t]{2}{*}{ Ethnicity1_3 } & 0.293 & 0.186 & -0.006 & -0.115 \\
\hline & $(0.518)$ & $(0.552)$ & $(0.584)$ & $(0.592)$ \\
\hline Ethnicity1_4 & - & - & - & - \\
\hline Constant & $\begin{array}{l}0.344 \\
(0.663)\end{array}$ & $\begin{array}{l}-2.942 * * * \\
(0.905)\end{array}$ & $\begin{array}{l}-4.446^{* * *} \\
(1.137)\end{array}$ & $\begin{array}{l}-5.027 * * * \\
(1.278)\end{array}$ \\
\hline Pseudo R2 & 0.026 & 0.099 & 0.113 & 0.115 \\
\hline Chi2 & & $28.00 * * *$ & $6.05^{* *}$ & 1.14 \\
\hline Observations & 353 & 353 & 353 & 353 \\
\hline
\end{tabular}

Robust standard errors in parentheses

$* * * \mathrm{p}<0.01, * * \mathrm{p}<0.05, * \mathrm{p}<0.1$ 


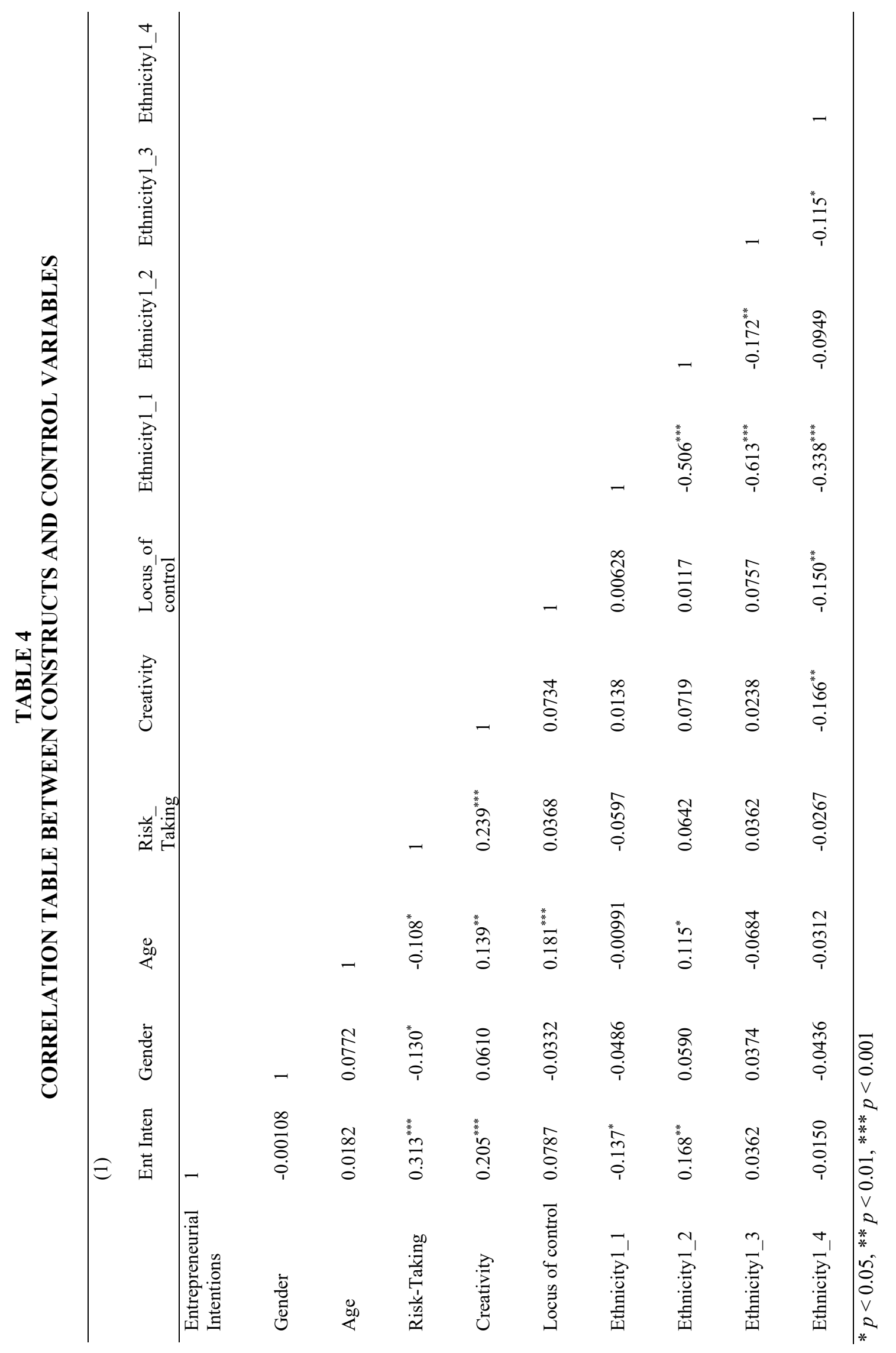




\section{DISCUSSION}

This study focused on three personality variables that may affect entrepreneurial intentions - risk propensity, creativity, and locus of control. We studied U.S. business school university students to obtain a sample of subjects before they started their own business because the perspectives of nascent entrepreneurs may differ from those of successful entrepreneurs. Additionally, this study does not suffer from a "survival bias" (Johnson et al., 2006) and includes a sample of those with entrepreneurial intentions whether their business later survived or failed. This study examined an essentially renewed role of management. This section will discuss the relevance of risk propensity and creativity as predictors of entrepreneurial intentions and some issues with the variable locus of control.

\section{Risk Propensity and Creativity}

The entrepreneurship literature has long sought to examine the predictors of individuals' entrepreneurial intentions (Liñán \& Fayolle, 2015). University students close to graduation have been of particular interest to scholars as a sample source of individuals with entrepreneurial intentions before starting their own businesses (Johnson, Parker, \& Wijbenga, 2006). Personality traits are among the critical predictors drawing interest from researchers (Brunel et al., 2017). In the present study, we sought to examine whether risk propensity and creativity were significant predictors of students' entrepreneurial intentions, especially in the time of the pandemic. The results clearly showed a strong and positive association between students' risk propensity and creativity and their intentions of starting their own businesses. Our results are consistent with prior research, which provides evidence that people with greater creativity and risk propensity are more likely to have entrepreneurial intentions than those with less risk propensity and creativity (Altinay et al., 2012; Gorgievski, Stephan, Laguna, \& Moriano, 2018; Kautonen, van Gelderen, \& Fink, 2015). Anecdotally, we believe that the pandemic-caused loss of traditional corporate jobs may have increased business school students' entrepreneurial intentions. However, it is beyond the scope of this study to determine the relative magnitude of entrepreneurial intentions because we did not perform a survey before the pandemic. Also, we do not know whether the students' intentions will change after the pandemic is over. However, we can clearly state that risk-taking and creativity are still two significant predictors of entrepreneurial intentions even under a pandemic circumstance.

\section{Locus of Control}

Concerning locus of control, this study did not find significant differences between students who had entrepreneurial intentions and those that did not. We used the best-known measure of locus of control (Rotter 1966), created by the initiator of the concept and used since 1966 by researchers. For many years, researchers have found evidence that entrepreneurs have an internal locus of control (Kaufman et al., 1995). Although some studies have supported Rotter's measures (Mescon \& Montanari, 1982; Cromie, 1987), other researchers have found no significant differences between entrepreneurs and non-entrepreneurs regarding locus of control (Begley \& Boyd, 1987). These studies focused on individuals who were already entrepreneurs, which left the possibility that the results reflected business success rather than a personal preference (Schjoedt \& Shaver, 2012). In a study of Romanian entrepreneurship college students, Luca, Casan, \& Tomulesco (2012) found a negative correlation between internal locus of control and participation in entrepreneurship courses. This finding further raises a possibility of a disparity between students of entrepreneurship and professional entrepreneurs regarding internal locus of control.

\section{Implications for Business School Educators}

We advise business school educators to provide counsel and assistance for nascent entrepreneurs by fostering creativity and providing management tools that help entrepreneurs reduce the perceived risk of starting their own business. We suggest that creativity may be increased by introducing innovative methods and materials with real-world applications, such as feasibility studies, business model development, and creative business plan production. Business school educators may urge nascent entrepreneurs to engage with community business leaders by attending local functions of the chamber of commerce, Better Business 
Bureau, and U.S. veterans' seminars. Public programs for entrepreneurs include the U.S. Small Business Administration (SBA) and Small Business Development Centers (SBDC). Other types of assistance for small businesses include professional consultants, suppliers/vendors, Service Score of Retired Executives (SCORE) sponsored by the U.S. Small Business Administration (SBA), and informal advisors (Strike, 2012).

Another critical action is to establish entrepreneurship centers that reach out into the community and connect with practitioners. Business school educators may foster entrepreneurship across university campuses by reaching out to engineering students, fine arts students, and education students who may have creative ideas within their areas of study but lack exposure to business operations. Business school educators should embrace creativity exercises among their students via their educational seminars. Moreover, research has demonstrated that creativity exercises enhance entrepreneurs' creative abilities (Schlee \& Harich, 2014).

\section{Limitations and Future Research}

This study was conducted at a regional state university in a southwestern U.S. state, with approximately 10,000 students. The participating students may or may not reflect the attitudes and thought patterns of business students in other areas of the U.S. or larger or smaller universities. While the measures used for risk propensity (Meertens \& Lion, 2008) and creativity (Creativity Audit Questionnaire, 2013) proved to be reliable, the use of updated locus of control scales, such as those developed by Schjoedt \& Shaver (2012), may render significant results in future studies. Additionally, larger sample sizes may increase reliability and be advisable in future studies.

Although the theory of planned behavior also proved to provide a solid theoretical base, scholars may employ other behavioral theories such as social cognitive theory (Bandura, 1986) in future studies. Future entrepreneurial intentions studies may include examining less-researched factors in this area, such as political party affiliation or religious practice and belief. Gender differences may also exist concerning entrepreneurial intentions. We strongly suggest that future studies focusing on ethnic minorities, such as African-Americans, may provide interesting results. In this study, we found that African-American students $(n=44)$ reported a strong interest in starting their own businesses. We invite future studies to examine this result with larger sample sizes.

\section{CONCLUSION}

We believe that the results of this study inform the theory and practice of entrepreneurship in the critical area of entrepreneurial intentions. Broadly, we seek to increase awareness among business school educators of the significance of entrepreneurship as a desirable career. We believe that one impact of the Covid-19 pandemic is expanding interest among individuals to start their own business. This study reinforces the evidence that personality factors influence entrepreneurial intentions beyond contextual factors, even the Covid-19 pandemic. We confirm studies worldwide supporting the effect of personality factors - risk propensity and creativity --on entrepreneurial intentions. Our results concerning locus of control also underscore the mixed results reported worldwide in the use of Rotter's (1966) scales (Schjoedt \& Shaver, 2012). Finally, we propose that creative measures undertaken by business school educators will enhance individuals' desire to take risks to start their own businesses.

\section{REFERENCES}

Ajzen, I. (1988). Attitudes, personality and behavior. Milton Keynes: Open University Press.

Ajzen, I. (1991). The theory of planned behavior. Organizational Behavior and Human Decision Processes, 50(2), 179-211.

Altinay, L., Madanoglu, M., Daniele, R., \& Lashley, C. (2012). The influence of family tradition and psychological traits on entrepreneurial intention. International Journal of Hospitality

Management, 31(2), 489-499. 
Arenius, P., \& Minniti, M. (2005). Perceptual variables and nascent entrepreneurship. Small Business Economics, 24(3), 233-247.

Bandura, A. (1986). Social foundations of thought and action: A social cognitive theory. Englewood Cliffs, N.J.: Prentice-Hall.

Begley, T.M., \& Boyd, D.P. (1987). Psychological characteristics associated with performance in entrepreneurial firms and smaller businesses. Journal of Business Venturing, 2, 79-93.

Bird, B. (1988). Implementing entrepreneurial ideas: The case for intention. Academy of Management Review, 13(3), 442-453.

Boyd, N., \& Vosikis, G. (1994). The influence of self-efficacy on the development of entrepreneurial intentions and actions. Entrepreneurship Theory \& Practice, 18(4), 63-77.

Brachert, M., Hyll, W., \& Sadrieh, A. (2019). Entry into self-employment and individuals' risk-taking propensities. Small Business Economics. https://doi.org/10.1007/s11187-019-00173-6

Brunel, O., Laviolette, E., \& Radu-Lefebvre, M. (2017). Role models and entrepreneurial intention: The moderating effects of experience, locus of control and self-esteem. Journal of Enterprising Culture, 25(2), 149-177.

Caliendo, M., Fossen, F., \& Kritiko, A. (2010). The impact of risk attitudes on entrepreneurial survival. Journal of Economic Behavior and Organization, 76(1), 1-39.

Carter, N., \& Han, J. (2015). Nascent entrepreneur. Retrieved December 16, 2020, from https://onlinelibrary.wiley.com/doi/epdf/10.1002/9781118785317.weom030072

Center for American Entrepreneurship. (2020). Why is entrepreneurship important? Retrieved December 20, 2020, from https://startupsusa.org/why-is-entrepreneurship-important/

Creativity Development \& Innovation Training Package for Small and Medium-sized Enterprises. (2013). Creativity audit questionnaire. Retrieved December 20, 2020, from http://www.icreateproject.eu/index.php?t=231

Cromie, S. (1987). Motivations of aspiring male and female entrepreneurs. Journal of Organizational Behavior, 8(3), 251-261.

Davis, G. (2004). Creativity is forever (5th ed.). Dubuque, IA: Kendall-Hunt.

do Paco, A., Ferreira, Raposo, J., Rodrigues, R., \& Dinis, A. (2011). Entrepreneurial intention among secondary students: Findings from Portugal. International Journal of Entrepreneurship and Small Business, 13(1), 92-106.

Douglas, E., \& Fitzsimmons, J. (2013). Intrapreneurial intentions versus entrepreneurial intentions: Distinct constructs with different antecedents. Small Business Economics, 41, 115-132.

Fairlie, R., \& Holleran, W. (2012). Entrepreneurship training, risk aversion and other personality traits: Evidence from a random experiment. Journal of Economic Psychology, 33(2), 366-378.

Fuller, C., Simmering, M., Atinc, C., Atinc, Y., \& Babin, B. (2016). Common methods variance detection in business research. Journal of Business Research, 69(8), 3192-3198.

Gartner, W., \& Liao, J. (2011). The effects of perceptions of risk, environmental uncertainty, and growth aspirations on new venture creation success. Small Business Economics, 39, 703-712.

Gorgievski, M.J., Stephan, U., Laguna, M., \& Moriano, J.A. (2018). Predicting entrepreneurial career intentions: Values and the theory of planned behavior. Journal of Career Assessment, 26(3), $457-$ 475.

Grant, J. (1996). The proactive personality scale as a predictor of entrepreneurial intentions. Int. Small Business Management, 34, 42-49.

Hisrich, R., Peters, M., \& Shepherd, D. (2002). Entrepreneurship. Retrieved December 16, 2020, from https://commercestudyguide.com/wp-content/uploads/2020/10/UNIT-I-ENGLISH.pdf

Hopp, C., \& Sonderegger, R. (2015). Understanding the Dynamics of Nascent EntrepreneurshipPrestart-Up Experience, Intentions, and Entrepreneurial Success. Journal of Small Business Management, 53(4), 1076-1096.

Hormiga, E., \& Bolívar-Cruz, A. (2014). The relationship between the migration experience and risk perception: A factor in the decision to become an entrepreneur. International Entrepreneurship and Management Journal, 10(2), 297-317. 
Hsiao, C., Lee, Y., \& Chen, H. (2016). The effects of internal locus of control on entrepreneurship: The mediating mechanisms of social capital and human capital. The International Journal of Human Resource Management, 27(11), 1158-1172.

Jackson, D. (1994). Jackson personality inventory: Revised manual. Port Huron, MI: Sigma Assessment Systems

Janney, J., \& Dess, G. (2006). The risk concept for entrepreneurs reconsidered: New challenges to the conventional wisdom. Journal of Business Venturing, 21(3), 385-400.

Johnson, P., Parker, S., \& Wijbenga, F. (2006). Nascent entrepreneurship research: Achievements and opportunities. Small Business Economics, 27, 1-4.

Judge, T., Bono, J., Ilies, R., \& Gerhardt, M. (2002). Personality and leadership: A qualitative and quantitative review. Journal of Applied Psychology, 87(4), 765-780.

Kaufman, P., Welsh, D., \& Bushmarin, N. (1995). Locus of control and entrepreneurship in the Russian Republic. Entrepreneurship Theory \& Practice, 20(1), 43-56.

Kautonen, T., van Gelderen, M., \& Fink, M. (2015). Robustness of the Theory of Planned Behavior in Predicting Entrepreneurial Intentions and Actions. Entrepreneurship Theory and Practice, 39(3), 655-674.

Ko, S., \& Butler, J. (2007). Creativity: A key link to entrepreneurial behavior. Business Horizons, 50(5), 365-372.

Koh, C. (1996). Testing hypotheses of entrepreneurial characteristics: A study of Hong Kong MBA students. Journal of Managerial Psychology, 11(3), 12-25.

Krueger, N. (2009). Entrepreneurial intentions are dead: Long live entrepreneurial intentions. In A.L. Carsrud \& M. Bra"nnback (Eds.), Understanding the entrepreneurial mind (pp. 51-72). New York, NY: Springer.

Krueger, N., Reilly, M., \& Carsrud, A. (2000). Competing models of entrepreneurial intentions. Journal of Business Venturing, 15(5-6), 411-432.

Laguia, A., Moriano, J., \& Gorgievski, M. (2019). A psychosocial study of self-perceived creativity and entrepreneurial intentions in a sample of university students. Thinking Skills and Creativity, 31, $44-57$.

Liñán, F., \& Fayolle, A. (2015). A systematic literature review on entrepreneurial intentions: Citation, thematic analyses, and research agenda. International Entrepreneurship and Management Journal, 11, 907-933.

Luca, M., \& Cazan, A. (2011). Involvement in entrepreneurial training and personality. Procedia - Social and Behavioral Sciences, 30, 1251-1256.

Luca, M., Casan, A., \& Tomulesco, D. (2012). To be or not to be an entrepreneur... Procedia - Social and Behavioral Sciences, 33(2012), 173-177.

Luthans, F., Avey, J., Avolio, B., Norman, S., \& Combs, G. (2006). Psychological capital development: Toward a micro-intervention. Journal of Organizational Behavior, 27(3), 387-393.

Marks, L. (1998). Deconstructing locus of control: Implications for practitioners. Journal of Counseling \& Development, 76, 251-260.

Meertens, R., \& Lion, R. (2008). Measuring an Individual's Tendency to Take Risks: The Risk Propensity Scale 1. Journal of Applied Social Psychology, 38(6), 1506-1520.

Melati, I., Areif, S., \& Baswara, S. (2018). Does financial background affect entrepreneur students' creativity: An investigation of how rich and poor students start their businesses. Journal of Entrepreneurship Education, 21(1), 1-11.

Mescon, T., \& Montanari, J. (1982). The personalities of independent and franchise entrepreneurs. An empirical analysis of concepts. Academy of Management Annual Meeting Proceedings.

Morrison, A., \& Johnston, B. (2003). Personal creativity for entrepreneurship: Teaching and learning strategies. Active Learning in Higher Education, 4(2), 145-158.

Nishimura, J., \& Tristan, O. (2011). Using the theory of planned behavior to predict nascent entrepreneurship. Academia, Revista Latinoamericana de Administración, 46, 55-71. 
O'Donnell, J. (2020). Weekly update on COVID-19's impact on business formation and entrepreneurship. Retrieved December 21, 2020, from https://eig.org/news/weekly-update-on-covid-19s-impact-onbusiness-formation-and-entrepreneurship-1210

Rotter, J.B. (1966). Generalized expectancies for internal versus external control of reinforcement. Psychological Monographs, 80(1), 1-28.

Rotter, J.B. (1975). Some problems and misconceptions related to the construct of internal versus external control of reinforcement. Journal of Consulting and Clinical Psychology, 43, 56-67.

Schjoedt, L., \& Shaver, K.G. (2012). Development and validation of a locus of control scale for the entrepreneurship domain. Small Business Economics, 39, 713-726.

Schlee, R., \& Harich, K. (2014). Teaching creativity to business students: How well are we doing? Journal of Education for Business, 89(3), 133-141.

Schmidt, J.J., Soper, J.C., \& Facca, T.M. (2012). Creativity in the entrepreneurship classroom. Journal of Entrepreneurship Education, 15, 123-131.

Schwarz, E.J., Wdowiak, M.A., Almer-Jarz, D.A., \& Breitenecker, R.J. (2009). The effects of attitudes and perceived environment conditions on students' entrepreneurial intent: An Austrian perspective. Education + Training, 51(4), 272-291.

Shapero, A. (1984). The entrepreneurial event. In C.A. Kent (Ed.), The environment for entrepreneurship. Lexington: Lexington Books.

Shapero, A., \& Sokol, L. (1982). Social dimensions of entrepreneurship. In C.A. Kent, D.L. Sexton, \& K.H. Vesper (Eds.), Encyclopedia of entrepreneurship (pp. 72-90). Englewood Cliffs: PrenticeHall.

Shrader, M., \& Finkle, T. (2015). Creative achievement \& intelligence among student entrepreneurs. Journal of Entrepreneurship Education, 18(2), 1-16.

Sloan, K. (2017). How entrepreneurs can reduce the financial risks of a new business. Retrieved December 16, 2020, from https://due.com/blog/entrepreneurs-can-reduce-financial-risks-newbusiness/

Sorgner, A., \& Fritsch, M. (2018). Entrepreneurial career paths: Occupational context and the propensity to become self-employed. Small Business Economics, 51, 129-152.

Sternberg, R., \& Lubart, T. (1996). Investing in creativity. American Psychologist, 51, 677-688.

Strike, V.M. (2012). Advising the family firm: Reviewing the past to build the future. Family Business Review, 25(2), 156-177.

Sun, H., Ni, W., Teh, P., \& Lo, C. (2020). The systematic impact of personal characteristics on entrepreneurial intentions of engineering students. Frontiers in Psychology, 11, 1072.

Timmons, J.A. (1994). New Venture Creation; Entrepreneurship for the 21st Century. Sydney: Irwin.

World Economic Forum. (2020). Discovering the real impact of COVID-19 on entrepreneurship. Retrieved December 20, 2020, from https://www.weforum.org/agenda/2020/06/how-covid-19will-change-entrepreneurial-business/

Zampetakis, L., Gotsi, M., Andriopoulos, C., \& Moustakis, V. (2011). Creativity and entrepreneurial intention in young people: Empirical insights from business school students. International Journal of Entrepreneurship and Innovation, 12(3), 189-199.

Zampetakis, L.A., \& Moustakis, V. (2006). Linking creativity with entrepreneurial intentions: A structural approach. The International Entrepreneurship and Management Journal, 2(3), 413428. 